\title{
Flashflood-related mortality in southern France: first results from a new database
}

\author{
Freddy Vinet ${ }^{1, a}$, Laurent Boissier ${ }^{1,2}$ and Clotilde Saint-Martin ${ }^{1,3}$ \\ ${ }^{1}$ UMR GRED University Paul Valery Montpellier/IRD, France \\ ${ }^{2}$ Generali, Paris, France \\ ${ }^{3}$ Irstea , Aix-en-Provence, France
}

\begin{abstract}
Over the last 25 years, flash floods in the South of France have killed almost 250 people. The protection of prone populations is a priority for the French government. It is also a goal of the 2007 European flood directive. However, no accurate database exists gathering the fatalities due to floods in France. Fatalities are supposed to be rare and hazardous, mainly due to individual behaviour. A Ph. D. work has initiated the building of a database gathering a detailed analysis of the circumstances of death and the profiles of the deceased (age, gender...). The study area covers the French Mediterranean departments prone to flash floods over the period 1988-2015. This presentation details the main features of the sample, 244 fatalities collected through newspapers completed with field surveys near police services and municipalities. The sample is broken down between huge events that account for two thirds of the fatalities and "small" events (34 \% of the fatalities). Deaths at home account for $35 \%$ of the total number of fatalities, mainly during huge events. $30 \%$ of fatalities are related to vehicles. The last part of the work explains the relations between fatalities and prevention and how better knowledge of flood-related deaths can help to improve flood prevention. The given example shows the relationship between flood forecasting and fatalities. Half of the deaths took place in a small watershed $\left(<150 \mathrm{~km}^{2}\right)$. It emphasizes the need for the dissemination of a complementary system of flash flood forecast based on forecasted rainfall depth and adapted to small watersheds.
\end{abstract}

\section{Introduction}

Governments and institutions view the safety of human life as a priority in case of disaster. In the European Union, the 2007 flood directive reaffirmed that the protection of human health in general is a major goal of flood prevention. Meanwhile, losses of life are often considered as hazardous and rare. Fatalities may occur when people put themselves in danger. But those assumptions do not always rely on any real observations. In Europe, there is little knowledge about who dies during flash flood, under which circumstances, where... To answer such basic questions, a database has been set up putting together nearly 250 fatalities that occurred in southern France between 1988 and 2015.

This paper introduces existing studies concerning flood-related fatalities and exposes the method employed to collect information on flash flood-related deaths. Then, the first results are exposed, identifying the profiles of dead people and the circumstances of fatalities. In the final part of this presentation, the limits and the expected outcomes of this study will be discussed, focusing on the flood warning issue and its relationship with loss of life.

\footnotetext{
a Corresponding author: freddy.vinet@univ-montp3.fr
}

\section{A loss of life reduction-orientated flood prevention}

\subsection{Preserving life: an objective of flood prevention policies}

\subsubsection{Legal requirements}

International and national frameworks of flood prevention regularly stress the necessity to prioritise loss of life reduction. The first principle is that the State and, in the present case, French State, is responsible for the safety of the citizens.

In 2007, a European directive on flood prevention required the members of the European Union to reinforce the diagnosis and prevention of flood risk. The preservation of health (including risk of loss of life) is one of the four goals of flood prevention.

At the French level, the safety of populations at risk is the first of the three major objectives of the National Strategy for Flood Risk Reduction (SNGRI) adopted in 2012: "Floods may be a serious, even fatal risk to populations" states the Strategy. One of the national priorities is to minimize the loss of human life by 
developing forecast, warning, safety and training to behaviours that saves.

\subsubsection{A loss of life reduction-orientated crisis management}

In addition to prevention, crisis management is largely devoted to safeguard and rescue people. Meteorological or hydrological forecast and warning services focus mainly on the reduction of human impacts and the need to warn people [1]. Thus, over the last ten years, the need for improved forecasting and warning is illustrated by the reinforcement of early warning systems and the emergence of private companies specialized in local forecasting of flash floods in southern France. In addition, a considerable amount of research aims to know the behaviour in case of floods better [2], [3], especially to enhance prevention messages.

Authorities and local risk managers are more and more sensitive to the mortality issue, partly because the responsibility of State and local authorities is engaged after disasters. After recent huge events, heavy human tolls have pointed out the responsibility of the State and local authorities. Judicial investigations and even trials are more and more frequent. Municipalities put state authorities on trial and citizen organisations file lawsuits against local authorities. After the 2010 Xynthia storm surge in Western France, people affected filed complaints against members of state administration and against the mayor of the municipality of la Faute-sur-Mer where 29 people died on $28^{\text {th }}$ February [4]. After the June 2010 Var flash floods that triggered 26 deaths, the French government commissioned a study [5] to assess the causes of death and the vulnerability of people. After recent floods near Nice on the French Riviera ( $3{ }^{\text {rd }}$ Oct. 2015), the State Administration asked for a complete survey of fatalities and a report on the exact circumstances of deaths. All those points show the growing importance of flood mortality issue.

\subsection{Fatalities due to flash floods in France}

Indeed, flash floods are the most dangerous type of flood - that cause a great number of fatalities - with dike breaks [6] and sea surge [7].

Table 1 lists the flood events that have triggered 20 fatalities or more in France since 1988. All those floods are flash flood events in the French Mediterranean region except the Xynthia sea surge in 2010. Indeed, the southeastern part of France is highly exposed to flash floods. In autumn, heavy rainfall (sometimes above $600 \mathrm{~mm}$ per day) strikes the French Mediterranean coast and the backcountry regions [8].

Besides such huge events, local flash floods can trigger fatalities with rainfall ranging from $100 \mathrm{~mm}$ to $300 \mathrm{~mm}$ per day. In 2014, 6 local flood events in southern France caused 15 deaths e.g. the floods in Lamalou-lesBains on $17^{\text {th }}$ September where 4 people died on a campsite.

\begin{tabular}{|c|c|c|}
\hline Date & Location & $\begin{array}{c}\text { Number of } \\
\text { fatalities }\end{array}$ \\
\hline $09 / 22 / 1992$ & Vaison-la-Romaine & 49 \\
\hline $11 / 12 / 1999$ & Aude & $30^{(1)}$ \\
\hline $09 / 08 / 2002$ & Gard & 25 \\
\hline $02 / 28 / 2010$ & $\begin{array}{c}\text { Western France } \\
\text { Xynthia) }\end{array}$ & $41^{(2)}$ \\
\hline $06 / 15 / 2010$ & Var & 26 \\
\hline $10 / 03 / 2015$ & Alpes-Maritimes & 20 \\
\hline
\end{tabular}

Table 1. Recent deadly flood in France ( $\geq 20$ deaths)

(1) more 5 people killed by landslide

(2) more 7 people killed by windstorm

This context makes the knowledge of human vulnerability a great challenge for Disaster Risk Reduction but the French government does not really address the epidemiology of flood-related death. There is no accurate census and/or epidemiologic study of floodrelated deaths. The National Health Service focuses mainly on post-disaster health consequences.

\section{Methods and sources}

\subsection{Available data on flood fatalities}

The starting point of this research was the compilation of the information contained in existing databases: the international CRED EM-DAT database, the basis of the Dartmouth Flood Observatory and the Prim.net website managed by the French Ministry of Ecology in charge of flood prevention. These databases are well-known and frequently used by researchers to get a global overview of mortality (see [9] in [10]). The CRED EM-DAT is the best known database [11]. It gives a list of events providing, when available, a number of fatalities. But the events with fewer than 10 deaths are not always included. Furthermore, the location of the fatalities is not accurate and the circumstances of death are not given. The Prim.net Database, managed by the French Ministry of Ecology, can be downloaded for free but, like the previous database, it only provides general observations. The census of flood fatalities is not exhaustive. Nevertheless, two other specific studies are especially dedicated to flood-related fatalities in France. The first study surveys fatalities in France from 1971 to 1995 [12]. The second is a paper based on the inventory of floodrelated deaths in four departments of southern France from 1316 to 1999 [13].

To complete the list of potentially fatal floods, research and reports on flash floods in southern France [14] have been collected. Since the end of the 1990s, all huge events are submitted to a specific back analysis report providing general information on deaths. But in those reports, as in the French Ministry of Ecology database, information is general and never gives details about the circumstances or the exact location of deaths. To add to the list of potentially fatal floods, the website 
of Meteo France (French national service of meteorological forecasting) called "pluies extremes": http://pluiesextremes.meteo.fr/index.php was used. The website offers a list of 105 major rainfall events in the study area for the period 1988 to 2014 .

Once the events listed, the next step was to verify, to locate in a GIS and to collect accurate information around each fatality.

\subsection{Study field}

The database was first compiled at the University of Montpellier based on the work of Antoine et al. [13] quoted here above. Then, the Ph D. of L. Boissier [15] completed the database core by reinvestigating existing dataset, defining the rules of data collection and providing a first analysis. The database is now being consolidated within the framework of Clotilde SaintMartin's Ph D.. The following guidelines steered the compiling of the database.

\subsubsection{Selected fatalities}

The originality of the approach is to collect information for each fatality. Thus, each case corresponds to a line in the database. The lines can then be aggregated by event (date), spatial unit or year. It is a real challenge to gather information about every individual victim [16]. Another original aspect of this database is that all fatalities are accurately georeferenced in a GIS database, whereas other studies [17] work on a larger sample of flash flood events but without accurate location of dead people. In this case, the statistical unit is "a flash flood with a fatality(ies)". The database concerning flood victims in the French Mediterranean region is called "Vict-In database".

The key criterion to select a flood-related fatality is the causal relation between flooding and the death. Jonkman and Kelman [18] define a "Flood fatality or flood-related fatality" as a "fatality that would not have occurred without a specific flood event. Synonyms and related terms include flood deaths, loss of life in floods, flood mortality and killed by flooding". Naturally, some uncertainty remains in this relation.

Immediate and differed deaths were distinguished (table 2). In case of drowning, it is rather easy to relate flood and death. It is more difficult to account for indirect death for example when people die during rescue. Thus, during the Nimes event in 1988, the direct human toll was of 9 but it rose to 11 when taking into account the 2 passengers of a helicopter that crashed during rescue operations. The relationship between the helicopter crash and the flood event is clear so those fatalities were included.

\begin{tabular}{|c|c|c|}
\hline DEATH & immediate & differed \\
\hline direct & weak uncertainty & high uncertainty \\
\hline indirect & $\begin{array}{c}\text { Medium } \\
\text { uncertainty }\end{array}$ & $\begin{array}{c}\text { Very high } \\
\text { uncertainty }\end{array}$ \\
\hline
\end{tabular}

Table 2. Types of flood-related death and degree of uncertainty in collected information
In fact, the information collected depends on the delay between the flood event and the death. If people do not die immediately from drowning or injury, it is difficult to collect data and to prove the connection with flooding because people are often admitted to hospital and their death is not published. Another delicate issue concerns suicides. After disasters, some cases are reported but it is difficult to link them to flooding as the disaster is often not the root cause of the suicide. No one can say if the person would have committed suicide if he or she had not been involved in flooding.

Moreover, unusual mortality was reported in retirement homes after evacuation during floods in 2010 [19]. It is also difficult to make a complete inventory of this type of death. For those reasons, this was not included in the survey.

Thus, the sample includes all the direct and indirect fatalities due to floods but excludes differed deaths.

\subsubsection{The covered period}

The studied period ranges from 1988 to 2015. 1988 was chosen as a starting point because it was the date of the flash floods in Nîmes ( $3^{\text {th }}$ October 1988) that triggered 11 fatalities. Also, the late 1980s and early 1990s saw a reinforcement of the national French flood prevention policy [20], [21]. Moreover, this period was homogeneous in socio-economic conditions (type of housing, use of cars). Finally, for this period, direct witnesses of flooding are still alive, which facilitates the collection of information.

\subsubsection{Selected area}

The selected area for the exhaustive census of fatalities covers the whole French region submitted to Mediterranean climate i.e. likely to be hit by flash floods in the autumn. It stretches from the Pyrenean Mountains to the Italian border (Fig. 1). This region gathers 10 departments i.e. more than $50,000 \mathrm{~km}^{2}$. Due to lack of time and considerable distance, two departments of the French Riviera (Var and Alpes-Maritimes) were not included for the entire period but only since 2010 . 


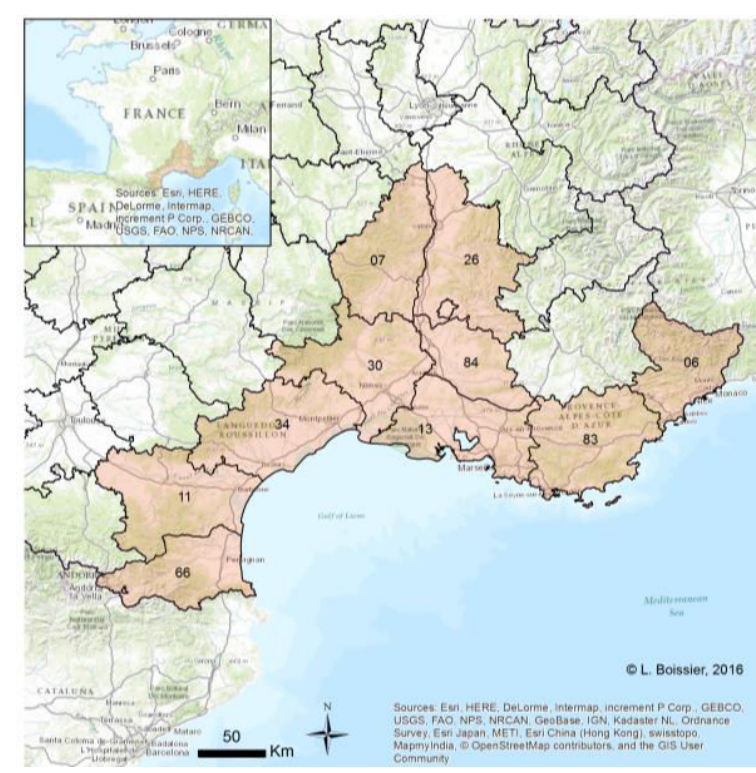

Figure 1. The study area

\subsection{Collected Information}

The aim of the database was to collect information on 3 aspects:

- Profile of dead people: gender, age, origin...

- Circumstances of death: hour, place...

- Elements on vulnerability drivers: human vulnerability (disability...), environment data (kind of house, of vehicle...)

A two pages Excel $\mathbb{C}$ sheet was filled for each case. Each death is georeferenced in a GIS database and linked to the Excel(C) sheet. The sheet includes narratives that provide detailed information on death conditions. For deaths at home, a special box collects the characteristics of the building (number of storeys, roof evacuation...). The database also mentions the sources of information (report, other database, newspaper...).

\subsection{Sources and verification of information}

Given the lack of databases in the public services, the first useful source was the press. Newspapers provide information on the death and sometimes publish a list of victims. Of course, that information has to be verified on the field.

Municipalities were the second source of information to confirm the figures collected in newspapers. Some municipalities had collected information especially on huge events e.g. the municipality of Vaison-La-Romaine hit by severe floods in September 1992. For recent events, firemen services in charge of rescue are a good source of information when they are willing to collaborate. The police services are not an interesting source of information, either they don't collect data or they can't publish it.

Finally, for each death, field recognition was undertaken where the death was likely to have occurred. Collected data concerns the water depth at the place of death and the characteristics of the environment (campsite, street, houses...) that can give information about how people died. Testimonies are also collected from residents in flood-prone zones.

\section{First results}

Through this database, a lot of information was collected. The goal of this presentation is not to show all the results, but to focus on the main outcomes that highlight the interest of the mortality in the diagnosis of the vulnerabilities and the improvement of flood prevention. Once collected and verified, the final sample adds up to 244 fatalities (Fig. 2).

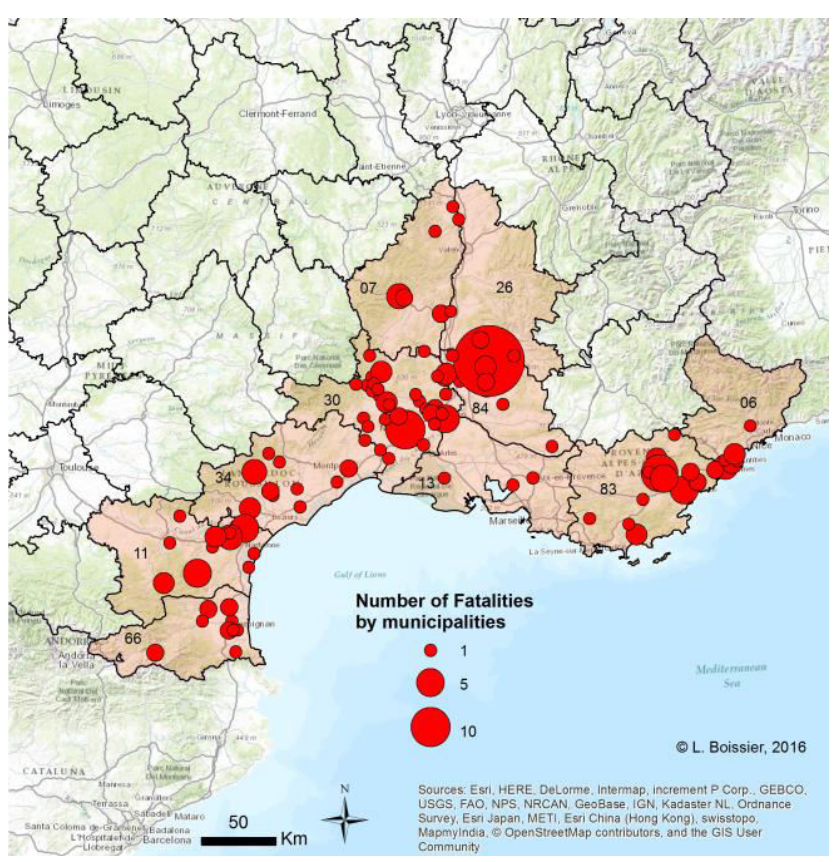

Figure 2. The spatial distribution of flood-related fatalities in southern France (1988-2015)

\subsection{Profile of victims}

\subsubsection{Gender and age}

The gender of 232 out of 244 dead people is known. There is no information about the remaining 12 cases, including 3 children. Men (142) represent more than $60 \%$. The results are consistent with other sources that highlight the male over-representation in flood-related deaths [22], [23]. Thus, in Jonkman and Kelman's study [18], covering 13 events of the years 1990-2000 in Europe and the United States (for 247 deaths), 72\% of dead people were male. No historical trend in sex ratio was found but it is noteworthy that male mortality is exaggerated in small events (see below) while the sex ratio is more balanced during huge events e.g. during the major disaster of Vaison-la-Romaine in 1992 (highest human toll of 49 dead people over the period) the sex ratio was $50 / 50$.

The exact age of dead people is known for 208 cases (Fig. 3). By adding more approximate information ("child", "in his seventies", "old man"...), this number 
rises to 212. Although the youngest victim is a 9 month old baby, overall, mortality mainly concerns elderly people. The median age is 54 . The sample was compared to the whole population of the studied area (Fig. 4). The sample was not compared to the entire population located in flood-prone areas. Indeed, this population is not well known as many places prone to runoff are not yet mapped. Secondly, due to the great number of vehiclerelated deaths and pedestrians, people living out of the identified flood prone zones are also exposed. The census of the year 1999 was chosen as it was an exhaustive census of the population and it is around the median date of the sample. Thus, people over 60 represent nearly half $(46 \%)$ of the sample while they represent about $24 \%$ of the entire population of the studied area. On the contrary, children under 15 years old make up only $7 \%$ of deaths while they represent $17 \%$ of the population. As previously noted [18], the greater vulnerability and exposure of children cannot be confirmed here.

The most represented category concerns men from 45 to 75 years old. Their relative impact in deaths is twice what they represent in the whole population. Women are over represented in upper age classes.

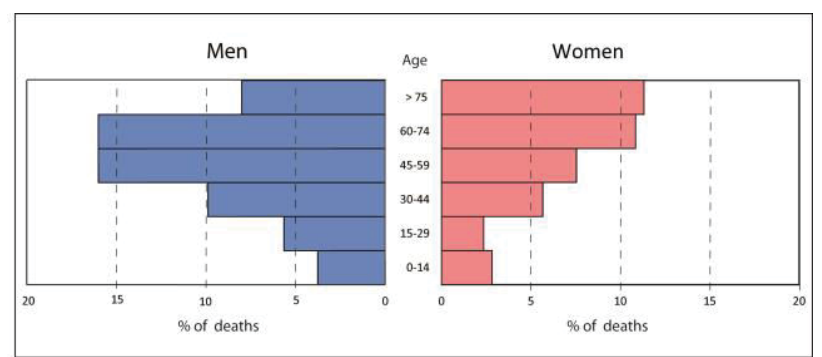

Figure 3. Population pyramid of flood-related deaths $(n=212)$

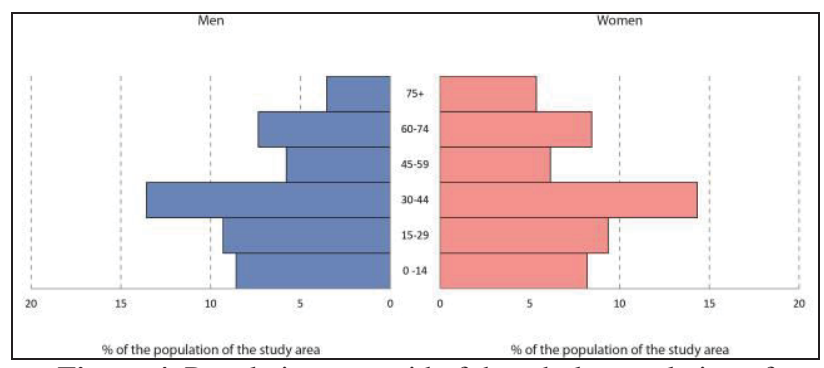

Figure 4. Population pyramid of the whole population of studied area (1999)

\subsubsection{Origin of people}

Concerning the origin of people, the underlying question is to verify if foreign people such as tourists are more vulnerable to floods than local people. Indeed, local populations are supposed to be more conscious of the danger as they are used to living in a region regularly hit by flash floods while foreign populations don't know the phenomenon and can be surprised [24]. Only 32 out of 244 people killed during floods were foreign people i.e. people who don't live in the French Mediterranean region. This number seems to be low but further investigations need to be carried out to measure and to relativize this figure with respect to the entire exposed population.
However, this number is mainly due to people that died at a campsite (see below). It is difficult to come to a solid conclusion because samples are too scarce to be cross-analyzed. Tourists are more sensitive to safety instructions and more respectful of evacuation orders [2]. Also, people on holidays are less inclined to dangerous behaviour (e.g. less belongings to protect).

\subsection{Circumstances of death}

\subsubsection{Time distribution of fatalities}

The annual distribution of flash flood-related deaths (Fig. 5) is consistent with the annual distribution of huge rainfall events (Fig. 6). $80 \%$ of fatalities occurred in the autumn (from September to December). This annual distribution is specific to southern France and can vary in other Mediterranean regions. In Spanish Catalonia, damageable flash floods start in August. In Texas, flash floods are concentrated in the summer (June to August).

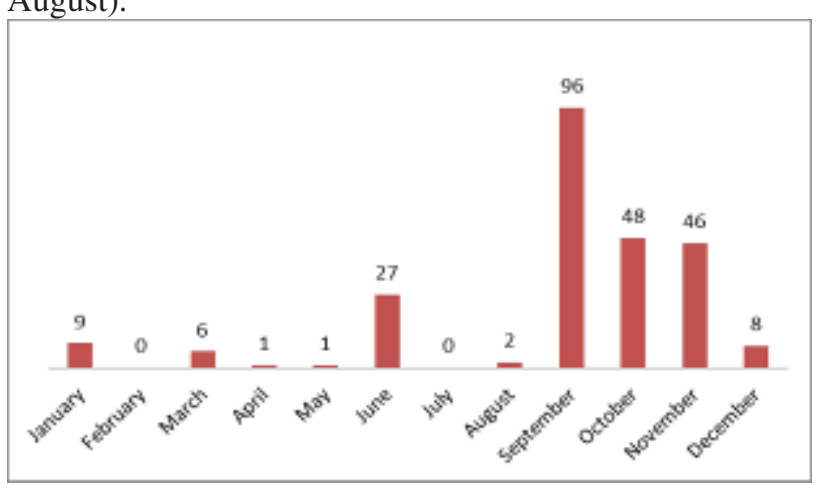

Figure 5. Monthly distribution of flood-related fatalities

Nevertheless, it does not exclude fatalities in any other season, for example in the summer when tourists are more present on the Mediterranean coast. Fatalities in June are due to the June 2010 single event in the department of Var when 26 people died [25], [5]. According to the database "Pluies extremes" of MeteoFrance, $83 \%$ of rainfall events over $200 \mathrm{~mm}$ per day are concentrated between September and December (Fig. 6). September seems to be over represented with respect to the number of rainfall events but the human toll of September is partly due to the "Vaison-la-Romaine" event (49 deaths in 1992).

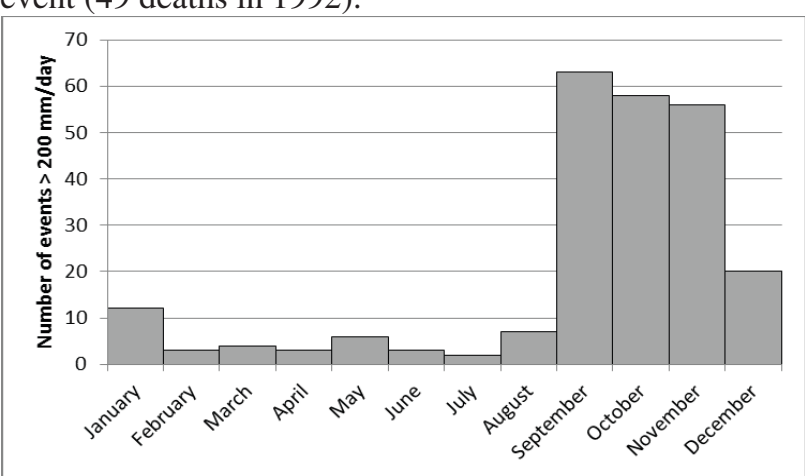

Figure 6. Monthly distribution of high rainfall events $(200 \mathrm{~mm}$ per day) in southern France (1988-2014) Source: Météo-France (http://pluiesextremes.meteo.fr/) 


\subsubsection{Daily distribution}

The daily distribution (Fig. 7) is fuzzier. First, it is difficult to inform the accurate hour of death as, at this time, weather conditions are difficult (storm, inaccessibility of road...). Often, corpses are found several hours or even days after the death. The distribution is linked to huge events e.g. the fatalities are concentrated over a short time lapse [16]. The accurate time of death is known for 89 people out of 244 and a proxy hour is given for 127 .

Although three moments seem to be privileged in terms of numbers of deaths (middle of the night, morning and evening), it is not really significant in terms of vulnerability or people's behaviour. This distribution is due to the occurrence of huge events. Only further exploration on a larger sample as [16] did for Gard 2002 on a small sample could bring solid outcomes. Nevertheless, many studies confirm twilight as a dangerous time. In Texas, $55 \%$ of motor-related fatalities occurred at night or twilight [26]. Spitalar et al. [17] came to the same conclusions on a large sample of flash floods collected in The United States of America.

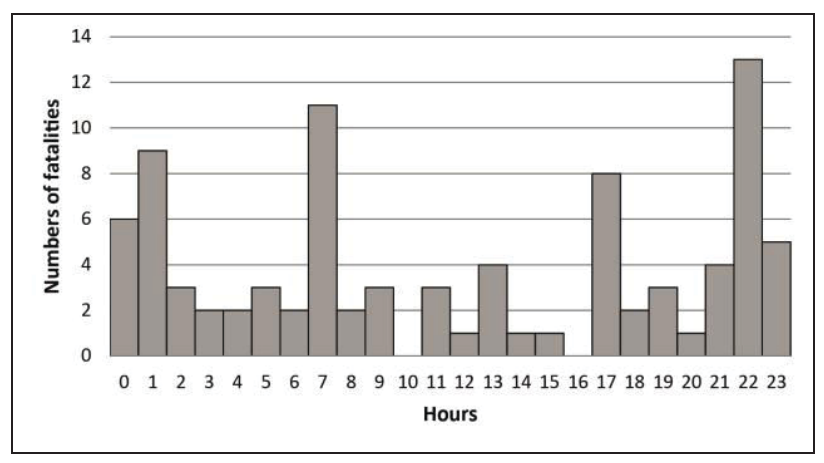

\begin{tabular}{|c|c|c|}
\hline Night $(\mathbf{0 - 6}$ h) & day $(\mathbf{6 - 1 8} \mathbf{~ h})$ & Evening (18-24h) \\
\hline 44 & 48 & 35 \\
\hline
\end{tabular}

Figure 7. Daily breaking down of death hours.

\subsubsection{Different circumstances of death}

The circumstances of death are highly determined by the place of death. We broke down the sample according to 4 criteria (Fig. 8).

(i) The first class put together people who died in a building ( $99 \%$ in their home and only $1 \%$ at work): it gathers $35 \%$ of fatalities.

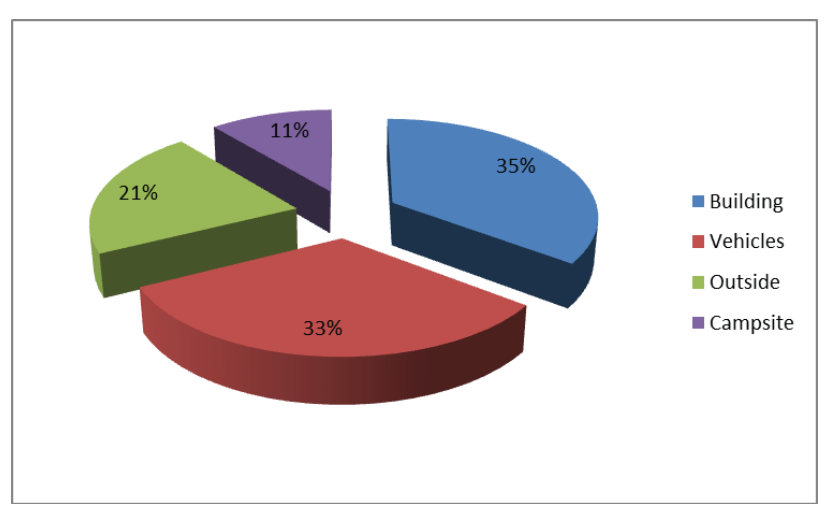

Figure 8. Circumstances of death during flash floods (1988$2015 \mathrm{n}=244)$

(ii) Vehicle-related fatalities are the second dominant group, making up $33 \%$ of the global sample. The kind of vehicle is accurately known for 45 out of 79 vehiclerelated deaths. 30 deaths are car-related. Others concern trucks, a helicopter and even a small boat that capsized during evacuation in 2005 in the Pyrénées-Orientales. This group is heterogeneous. It comprises people who were found drowned in their car, carried away by flows, and people who were found outside of their car but for whom it was certain that their death was linked to a vehicle. People who died when trying to remove their car from an inundated car park must also be added. The percentage of car-related flood drownings depends on the country and flood type. In Texas, $80 \%$ of flood-related fatalities are motor vehicle-related [26] but, for all the US, the rate announced by French et al. [22] was near $40 \%$. It rises to $63 \%$ according to a more recent study [27]. River crossing explains a great part of motor vehicle-related deaths as behaviour examination shows. According to the Federal Emergency Administration [28], a $0.17 \mathrm{~m}$ water depth can make a vehicle float and above $0.6 \mathrm{~m}$, the vehicle can be carried away by rushing waters. A sub-category came out after the $3^{\text {rd }}$ October 2015 event in the Alpes-Maritimes department when 9 people died going to retrieve their car in underground car-parks. Those people regularly removed their car when heavy rainfall was announced, but this event was particularly huge and lead time was too short. Those 9 people remained trapped in the car parks. Two similar cases had already been recorded in June 2010 in Draguignan.

(iii) The third category is pedestrians. It concerns $21 \%$ of people. A low water depth $(0.5 \mathrm{~m})$ is sufficient to carry people away.

(iv) The total number of people found dead in or near a campsite is 27 i.e. $11 \%$ of the sample. Deaths in campsites are grouped in late summer and early autumn: 24 out of the 27 people who died in campsites died in September. This month is particularly dangerous because it combines the end of the touristic season (the weather is still fair in September) and the beginning of the rainy season.

The tourist population is a key issue in a region (southern France) where the economy is based on tourism. The peak of tourist season is in summer (July and August) when the weather is dry and sunny. Nevertheless, due to the global warming and the ageing 
of population in developed countries, the touristic season is likely to stretch to a larger period of the year. Moreover, climate change can induce heavy rainfall earlier in the dry summer season but nothing is confirmed yet. The frequency of heavy rainfall could increase due to climate change (projection for 2070-2100) while intensity is not likely to change [29], [30].

The French Ministry of Ecology in charge of flood prevention has carried out studies on the exposure of campsites in France and identified 2,200 campsites in flood prone zones in France (all kinds of floods including sea surge). Strict rules are applied locally for the opening dates of campsites (those exposed to flash flood are supposed to be closed after $31^{\text {st }}$ August). Those rules have been reminded in a circular (ministerial order) after the flash flood of Lamalou-les-Bains (Herault department, Southern France) on $17^{\text {th }}$ September where 4 people died on a campsite. Nevertheless, more and more campsites are now opened all year long and mobile homes or caravans become permanent housing for lowincome people such as the retired.

\subsubsection{Dangerous behaviours}

Inappropriate behaviour is often pointed out to explain fatalities. Many studies have been led on the behaviour of people facing floods [2], [3] [31]. Fitzgerald et al. [32] estimate that in Australia, 90\% of fatalities would be related to inappropriate behaviour. But behaviour facing a flood varies tremendously. Of course, there is always a bias surveying people that have escaped from death whereas it is impossible to question people who died from drowning. So we tried to draw conclusions about general behaviour that led to fatal decisions by retracing the circumstances of death. Nevertheless some discrepancies among different populations can be pointed out.

(i) Dangerous behaviour at home or outdoors (pedestrians). In 22 cases, dangerous behaviour is associated to the willingness of people to save other people, belongings or pets [31]. The case of the people who tried to save their car in an underground carpark has already been mentioned. But eight cases of people who put themselves in danger and died trying to save a pet were also identified. Wilson [33] assumes that the affective or economical value of goods often prevails over the perception of danger. For example, we can quote the case of a man who crossed the overflowing river in June 2010 to save his dog on the other bank.

(ii) Dangerous behaviour while driving. Among the 79 vehicle-related deaths of our sample, 26 cases are listed on fording although the ford is often indicated as inundated by temporary road signs. Many works demonstrated the vulnerability of cars carried away by flows [2]. Finally, the underestimation of risk can be explained by the use of $4 \times 4$ vehicles which give a false sense of security (conveyed by advertising). 7 out of 30 car-related deaths are linked to four wheel drive vehicles i.e. $23 \%$, which is over the average representation of this kind of vehicle. The vulnerability of other vehicles such as camper-vans that float easily must also be mentioned.
In campsites, they are more dangerous than tents as people inside become aware of flooding later, when water depth is already too high for them to escape. Moreover, the attitude of elderly people who sometimes drive into water flows without being conscious of the danger is also questionable. Of course it is not specific to old people but many cases have been observed in 2014 and 2015. Could a slight mental disease or some medication alter the decision making process when facing danger? Further investigations are necessary to answer such a question.

\section{Fatalities and hydrological/hydro- graphical parameters}

\subsection{Huge and local events}

\subsubsection{Huge events concentrate $66 \%$ of deaths}

To further analyse flood-related fatality drivers, two samples were separated. Two kinds of events has been identified: on the one hand, six huge events were analysed, each of them accounting for more than 10 dead people (Fig. 9). They include 161 fatalities i.e. $66 \%$ of the entire sample (244 fatalities). On the other hand, 37 other events remain (that were called "local events") with human tolls below 10 fatalities each (Fig. 10).

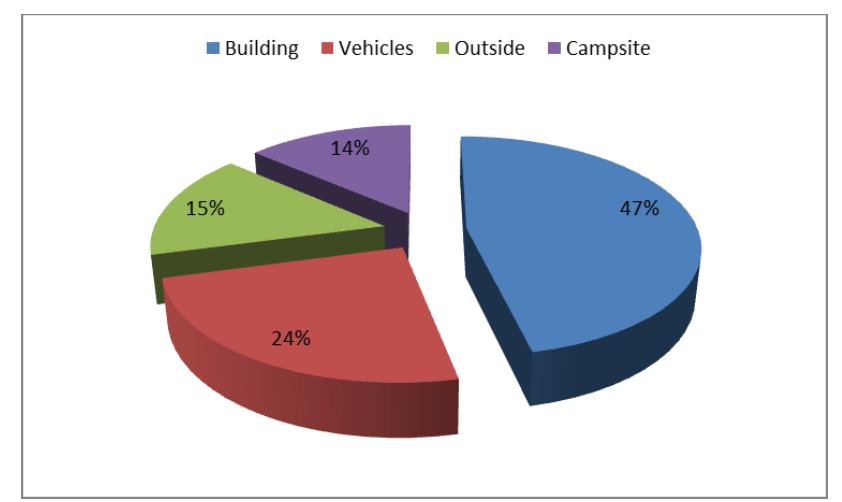

Figure 9. Death circumstances during huge events $(\geq 10$ fatalities; $\mathrm{n}=161$ deceases)

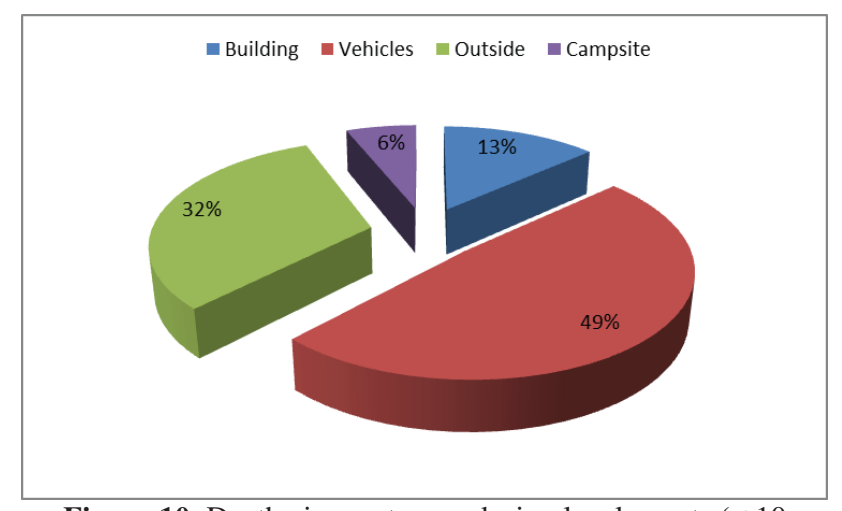

Figure 10. Death circumstances during local events $(<10$ fatalities; $\mathrm{n}=83$ ) 


\subsubsection{Different profile and circumstances} depending on the kind of event.

For those huge events, the number of people who died in their house is overrepresented. During this kind of event, big rivers overflow and water depth sometimes reaches several meters. Dyke failure is also relevant of this kind of event like in 1999 (30 fatalities including 5 dyke break-related) or 2002 (23 people died and among them, 5 behind a dyke break). Dyke failure exposes large urban zones to flooding and people are found trapped inside their houses.

Concerning "local events", i.e. events of small spatial extension, vehicle-related deaths prevail. Fatalities are linked to fording on small dry thalwegs that are numerous in Mediterranean climate. During those "small" events, men are over represented and risk-taking is decisive in behaviours leading to death.

\subsection{Watershed size upstream fatalities places}

Using the Cartographic database "CBD CARTHAGE" edited by IGN, the size of the watershed upstream of each georeferenced death was calculated. This value is known with accuracy for 203 cases (Fig. 11). The sizes of watersheds stretch from $0.2 \mathrm{~km}^{2}$ to 95 $500 \mathrm{~km}^{2}$ (the latter is the Rhône river basin where people died after dyke break in 2003 near the mouths). Half of the deaths occurred in less than $150 \mathrm{~km}^{2}$ wide basins, many of those watersheds are non-permanent rivers. Peak discharge up to $15 \mathrm{~m}^{3} / \mathrm{s} / \mathrm{km}^{2}$ was observed in such small Mediterranean basins [34], [35]. It explains why the quick onset of water level is an aggravating circumstance during flash floods. It also points out the problem of real time forecasting, which is a key issue in small basins.

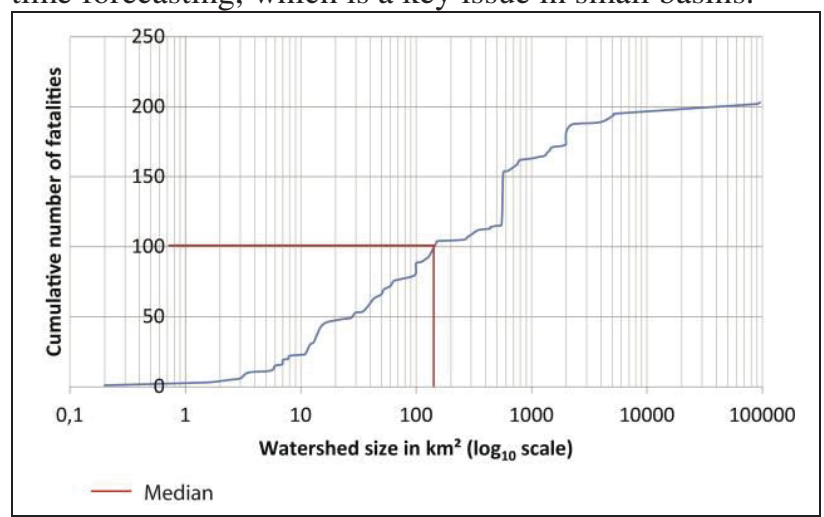

Figure 11. Distribution of fatalities according to the watershed size (data is presented from biggest to smallest)

\section{Conclusions and discussion on perspectives}

\subsection{The evolution of flood-related mortality}

The final aim of this database is to help reduce the human toll of floods. So, given the data exposed before, what conclusions can be exposed on prevention and especially early warning? Sharif et al. [36] estimate that "the annual flood-fatality rates are decreasing significantly. A combination of improved hydrometeorological forecasting, educational programs aimed at enhancing public awareness of flood risk and the seriousness of flood warnings, and timely and appropriate action by local emergency and safety authorities will help further reduce flood fatalities in Texas".

Of course, historical catastrophic events causing hundreds of deaths seem to be a thing of the past [37] but the number of fatalities is still too high. It is not possible to reduce to zero the number of deaths but it might be possible to reduce the human toll especially for huge events.

The annual evolution of the number of fatalities (Fig. 12) seems to indicate a decrease of huge annual tolls. It does show a positive effect of prevention measures but further research is being implemented to assess the number of fatalities especially according to the exposed population. Also, it must be noted that the database only concerns the Mediterranean regions. Accounting for all flood events in France would show that the decreasing number of fatalities is not definitive. New risks appear like sea surges (41 people died in 2010) or local runoff in urban areas, even outside of Mediterranean regions. A forthcoming extension of the Vict-In DB is planned to cover all of France.

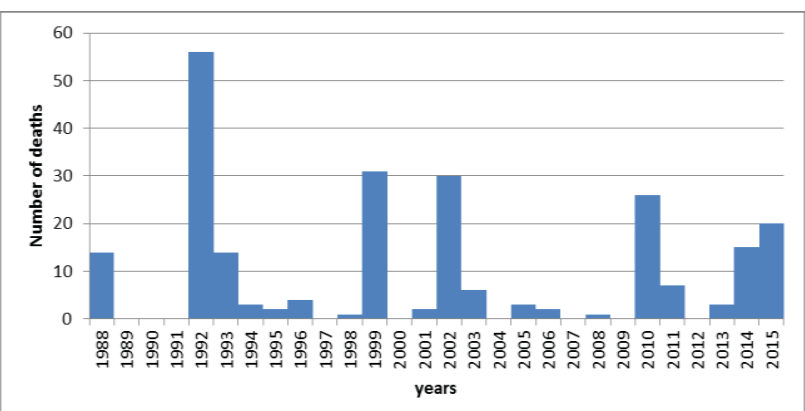

Figure 12. Evolution of the annual number of deaths since 1988

\subsection{Mortality and prevention through early warning}

The flood warning issue is interesting to illustrate the usefulness of accurate knowledge of flood-related mortality.

The French official flood warning system is now handled by the SCHAPI (French Central Service of Hydrometeorology and Support to Flood Forecasting) created in June 2003. It provides support to Flood Forecasting Services (SPC) and ensures a hydrometeorological watch on flow-gauged basins.

The status of the rivers was studied according to flood warning system. When comparing the location of deaths to the gauged and monitored rivers map, 123 (54\%) out of 227 fatalities occurred on rivers where a flood warning system did not exist (Fig. 13). It is difficult to draw conclusions on this data. Indeed, the French state administration argues that, without early flood warning service, the toll would be worse, which is undeniably true. 
The Vict-in database is now being carried out by Clotilde Saint-Martin as part of her PhD work. It has been paired up with a more general impact database. Put together, both those databases will help to test and validate a flash-flood impact model developed during the thesis.

This impact model is being implemented within the French institute called Irstea. It is based on a current flood warning method called AIGA that will be crossed with an indicator of the exposure to flooding. AIGA is a flood warning system based on a simple distributed hydrological model run at a $1 \mathrm{~km}^{2}$ resolution using real time radar rainfall information [38]. The flood warnings, produced every 15 minutes, result of the comparison of the real time runoff data produced by the model with statistical runoff values calculated with the SHYREG method [39]. AIGA may be called innovative as it also gives flooding information for small watersheds (> $\left.10 \mathrm{~km}^{2}\right)$.

Despite the low annual number of flash flood fatalities (9 per year), the preservation of life is a key issue in southern France. After each deadly flood event, political debates flare up in newspapers to point out either the failure of forecasting, the rise of impervious areas or the uncontrolled urbanization process.

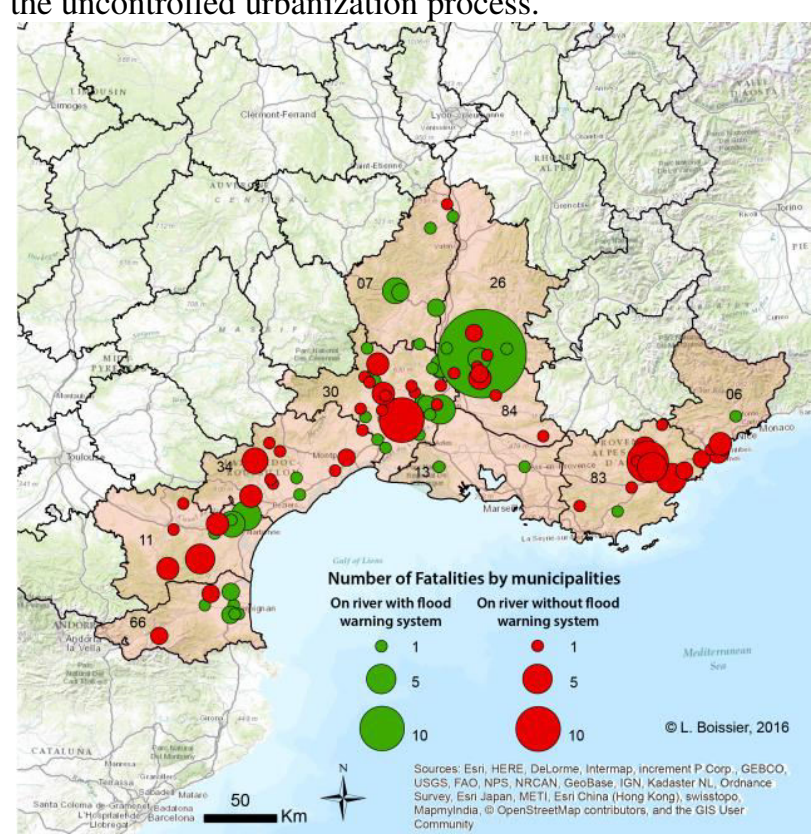

Figure 13. Location of fatalities regarding flood warning system

Only an accurate long term census of human and economic tolls can provide elements to answer such questions. The building of the Vict-In DB aims to add value to this assessment process.

\section{References}

1. Gruntfest E. and Handmer J.W. (2001). Coping with Flash Floods. Kluwer Academic Publishers, Dordrecht, The Netherlands, $322 \mathrm{pp}$.

2. Ruin I, (2007). Conduite à contre-courant. Les pratiques de mobilités dans le Gard: facteurs de vulnérabilité aux crues rapides. Thèse de doctorat, Université Grenoble I.

3. Morss R. E., Mulder K. J., Lazo J. K., Demuth J.L. (2015). How do people perceive, understand, and anticipate responding to flash flood risks and warnings? Results from a public survey in Boulder, Colorado, USA. Journal of Hydrology. Online publication date: 1-Dec-2015. doi:10.1016/j.jhydrol.2015.11.047

4. Steinlé-Feuerbach M.-F. (2015). Xynthia : les responsabilités pénales (Trib. corr. des sables d'Olonne, 12 déc. 2014, n 877/2014), Journ. Acc.Cat., CERDACC

5. Belin P. and Moulin C. (2013). Analyse des situations de danger dans le cadre du retour d'expérience des inondations des 15 et 26 juin 2010 dans le Var sur les situations de danger. La Houille Blanche, (1), 10-15.

6. Jonkman S. N., Maaskant B., Boyd E. and Levitan M. L. (2009). Loss of life caused by the flooding of New Orleans after hurricane Katrina: analysis of the relationship between flood characteristics and mortality. Risk Analysis, (9), 676-698

7. Lumbroso D. M. and Vinet F. (2011). A comparison of the causes, effects and aftermaths of the coastal flooding of England in 1953 and France in 2010. Nat. Hazards Earth Syst. Sci., 11, 23212333

8. Boudevillain B., Argence S., Claud Ch., Ducrocq V., Joly B., Joly A., Lambert D., Nuissier O., Plu M., Didier Ricard D., Arbogast P., Berne A., JeanPierre Chaboureau J.P., Chapon B., Crépin F., Delrieu G., Doerflinger E., Funatsu B.M., Kirstetter P.E., Masson F., Maynard K., Richard E., Sanchez E., Terray L. and Walpersdorf A. (2009). Cyclogenèses et précipitations intenses en région méditerranéenne : origines et caractéristiques. $\mathrm{La}$ Météorologie, (66), 18-28

9. Fang J., Li M. and Shi P. (2015). Mapping Flood Risk of the World in Shi P. and Kasperson R. (Eds.) World Atlas of Natural Disaster Risk, 69-102. doi: http://dx.doi.org/10.1175/WCAS-D-14-00030.1

10. Shi, P. and Kasperson, R. (Eds.) (2015). World atlas of natural Disaster Risk, 368 p.

11. Wallemacq, P., and Below, R. (2015), "The human cost of natural disasters: A global perspective", Brussels, Belgium: Centre for Research on the Epidemiology of Disasters.

12. Geosciences Consultants. (1995). Mise en sécurité des populations exposées à des risques de crues et d'inondations. Paris.

13. Antoine J.-M., Desailly B. and Gazelle F. (2001). Les crues meurtrières, du Roussillon aux Cévennes. Annales de Géographie, 110 (622), 597-623

14. Huet P., Martin X., Prime J.L., Foin P., Laurain Cl., Cannard Ph. (2003). Retour d'expérience des crues de septembre 2002 dans les départements du Gard, de l'Hérault, du Vaucluse, des Bouches-du-Rhône, de l'Ardèche et de la Drôme. MEDD-IGE, 133 p. + annexes. 
15. Boissier L. (2013). La mortalité liée aux crues torrentielles dans le sud de la France : une approche de la vulnérabilité humaine face à l'inondation. Thèse université Paul Valéry Montpellier, $212 \mathrm{p}$.

16. Ruin I., Creutin J.D., Anquetin S., Lutoff C. (2008). Human exposure to flash floods - Relation between flood parameters and human vulnerability during a storm of September 2002 in Southern France. Journal of Hydrology 361, 199-213.

17. Špitalar M., Jonathan J. Gourley J., Lutoff C. Kirstetter P.E., Brilly M. and Carr N. (2014) Analysis of flash flood parameters and human impacts in the US from 2006 to 2012. Journal of hydrology, $\quad 519, \quad 863-870$ http://dx.doi.org/10.1016/j.jhydrol.2014.07.004

18. Jonkman S. N. and Kelman I. (2005). An analysis of the causes and circumstances of flood disaster deaths. Disasters, 29 (1), 75-97

19. Mantey K., Coccoz F., Boulogne O., Torrents R., Guibert N., Six C. and Malfait P. (2012). Surmortalité associée à un déplacement en urgence des personnes âgées hébergées en institution suite aux inondations du Var en 2010. Geriatr Psychol Neuropsychiatr Vieil., 10(4), 373-382. doi:10.1684/pnv.2012.0374

20. Carré C. (2006). Les évolutions en France dans la théorie et les pratiques d'une gestion territoriale du risque: l'application au cas des inondations. Annales de géographie, (648), 133-153

21. Pottier N., Penning-Rowsell E., Tunstall S. and Hubert G. (2005). Land use and flood protection: contrasting approaches and outcomes in France and in England and Wales. Applied Geography, (25), 127

22. French J., Ing R., Von Allmen S. and Wood R. (1983). Mortality from flash floods: a review of national weather service reports, 1969-81. Public Health Reports, 98(6), 584-588

23. Coates L. (1999). Flood Fatalities in Australia, 1788-1996. Australian Geographer, 30(3), 391-408

24. Hubert G. and De Vanssay B. (2005). Le risque d'inondation et la cartographie réglementaire. Analyse de l'efficacité, des impacts et de l'appropriation locale de la politique de prévention. Rapport du programme MEDD-EPR, $188 \mathrm{p}$.

25. Vinet F., Lumbroso D., Defossez S. and Boissier, L. (2012). A comparative analysis of the loss of life during two recent floods in France: The sea surge caused by the storm Xynthia and the flash flood in Var. Nat. Hazards, 61 (3), 1179-1201.

26. Sharif H. O., Hossain M. M., Jackson T. and BinShafique S. (2012). Person-Place-Time. Analysis of Vehicle Fatalities Caused by Flash Floods in Texas. Geomatics Natural Hazards \& Risk, 3(4), 311-23. doi:10.1080/19475705.2011.615343.

27. Ashley S. T. and Ashley W. S. (2008). Flood Fatalities in the United States. Journal of Applied Meteorology and Climatology, 47(3), 805-818

28. FEMA (2004), Are You Ready? An In-depth Guide to Citizen Preparedness. Available online at: https://www.fema.gov/pdf/areyouready/areyouready _full.pdf (accessed 28 February 2016).
29. Soubeyroux J.M., Neppel L., Veysseire J.M., Tramblay Y., Carreau J. and Gouget V., (2015). Evolution des précipitations extrêmes en France en contexte de changement climatique. La Houille Blanche, (1), 27-33.

30. Tramblay, Y., Neppel, L., Carreau, J. and Sanchez-Gomez, E, (2012). Extreme value modelling of daily areal rainfall over Mediterranean catchments in a changing climate. Hydrological Processes, 26, 3934-3944 doi:10.1002/hyp.8417

31. Becker J. S., Taylor H. L., Doody B. J., Wright K. C., Gruntfest E. and Webber D. (2015). A Review of People's Behavior in and around Floodwater. Wea. Climate Soc., (7), 321-332.

32. Fitzgerald G., Du W., Jamal A., Clark M. and Hou X.-Y. (2010) Flood fatalities in contemporary Australia (1997-2008). Emergency Medicine Australasia, 22(2), 180-186 doi:10.1111/j.17426723.2010.01284.x.

33. Wilson T. (2006) Les risques de blessures et de décès par imprudence lors des inondations. Responsabilité et environnement, 43, p. 57-63

34. Gaume E., Livet M., Desbordes M. and Villeneuve J. P. (2004). Hydrological analysis of the river Aude, France, flash flood on 12 and 13 November 1999. Journal of Hydrology, 286, 135-154

35. Gaume E., Bain V., Bernardara P., Newinger O., Barbuc M., Bateman A., Blaškovičová L., Blöschl G., Borga M., Dumitrescu A., Daliakopoulos I., Garcia J., Irimescu A., Kohnova S., Koutroulis A., Marchi L., Matreata S., Medina V., Preciso E. and Sempere-Torres D. (2009). A compilation of data on European flash floods. Journal of Hydrology, 367(12), 70-78

36. Sharif, H. O., Terrance L. Jackson T.L., Hossain M. M., and Zane D. (2015). Analysis of Flood Fatalities in Texas ». Natural Hazards Review 16 (1): 04014016. doi:10.1061/(ASCE)NH.15276996.0000145 .

37. Boudou M. (2015). Approches multidisciplinaires pour la caractérisation d'inondations remarquables. Enseignements tirés de neuf événements en France (1910-2010) Thèse de doctorat Université Paul Valéry Montpellier /Irstea 462 p. + annexes.

38. Javelle P., Demargne J., Defrance D., Pansu J., and Arnaud P. (2014). Evaluating flash-flood warnings at ungauged locations using post-event surveys: a case study with the AIGA warning system. Hydrological Sciences Journal, 59(7), 1390-1402

39. Arnaud P., Aubert Y., Organde D., Cantet P., Fouchier C. and Folton N. (2014). Estimation de l'aléa hydrométéorologique par une méthode par simulation: la méthode SHYREG : présentation performances - bases de données. La Houille Blanche (2), 20-26. 